\title{
Exploring Marine Environments for the Identification of Extremophiles and Their Enzymes for Sustainable and Green Bioprocesses
}

\author{
Paola Di Donato ${ }^{1,2, *}$, Andrea Buono ${ }^{3} \mathbb{D}$, Annarita Poli ${ }^{1}$, Ilaria Finore ${ }^{1} \mathbb{C}$, \\ Gennaro Roberto Abbamondi ${ }^{1}$, Barbara Nicolaus ${ }^{1}$ and Licia Lama ${ }^{1, *(1)}$ \\ 1 Institute of Biomolecular Chemistry, National Research Council of Italy, Via Campi Flegrei 34, \\ 80078 Pozzuoli, Naples, Italy; apoli@icb.cnr.it (A.P.); ilaria.finore@icb.cnr.it (I.F.); \\ roberto.abbamondi@icb.cnr.it (G.R.A.); bnicolaus@icb.cnr.it (B.N.) \\ 2 Department of Science and Technology, University of Naples "Parthenope", Centro Direzionale Isola C4, \\ 80143 Naples, Italy \\ 3 Department of Engineering, University of Naples "Parthenope", Centro Direzionale Isola C4, 80143 Naples, \\ Italy; andrea.buono@uniparthenope.it \\ * Correspondence: paola.didonato@uniparthenope.it (P.D.D.); licia.lama@icb.cnr.it (L.L.); \\ Tel.: +39-081-5476625 (P.D.D.); +39-081-8675071 (L.L.)
}

Received: 1 December 2018; Accepted: 22 December 2018; Published: 28 December 2018

\begin{abstract}
Sea environments harbor a wide variety of life forms that have adapted to live in hard and sometimes extreme conditions. Among the marine living organisms, extremophiles represent a group of microorganisms that attract increasing interest in relation to their ability to produce an array of molecules that enable them to thrive in almost every marine environment. Extremophiles can be found in virtually every extreme environment on Earth, since they can tolerate very harsh environmental conditions in terms of temperature, $\mathrm{pH}$, pressure, radiation, etc. Marine extremophiles are the focus of growing interest in relation to their ability to produce biotechnologically useful enzymes, the so-called extremozymes. Thanks to their resistance to temperature, $\mathrm{pH}$, salt, and pollutants, marine extremozymes are promising biocatalysts for new and sustainable industrial processes, thus representing an opportunity for several biotechnological applications. Since the marine microbioma, i.e., the complex of microorganisms living in sea environments, is still largely unexplored finding new species is a central issue for green biotechnology. Here we described the main marine environments where extremophiles can be found, some existing or potential biotechnological applications of marine extremozymes for biofuels production and bioremediation, and some possible approaches for the search of new biotechnologically useful species from marine environments.
\end{abstract}

Keywords: extremophiles; extremozymes; biofuels; bioremediation; microwave; satellite remote sensing

\section{Introduction}

Seas and oceans cover more than $70 \%$ of the Earth's surface and harbor a wide variety of life forms that have adapted to live in hard and sometimes extreme conditions. The 'marine microbiome', i.e., the microbial species living in marine environments, play an important ecological role and possess an enormous potential for several biotechnological applications. The global bacterial marine biomass accounts for about $5.4 \times 1029$ cells and it is distributed in all the marine ecosystem from the open waters (ocean and seas), to the tidal regions, the seafloor and the sub-seafloor, the polar sea ice masses, and brines [1]. The complex of microorganisms hosted in marine environments belong to all of the three domains of life, i.e., Eukarya, Bacteria, and Archaea (Figure 1), although the great majority of them belong to the latter two domains. The sequencing of 16S rRNA of marine microbial species has 
evidenced a high taxonomical diversity of marine Bacteria and Archaea; indeed, it has been possible to identify as prevailing phyla the following ones: Alphaproteobacteria, Actinobacteria, Acidobacteria Cyanobacteria, Deltaproteobacteria, Gammaproteobacteria, and Flavobacteria [1] A significant share of marine Bacteria and Archaea belong to the group of extremophiles, i.e., those microorganisms that are able to live and thrive in extreme chemical and physical conditions [2]. The extremophiles are classified according to the physical or chemical parameters that characterize the environmental conditions in which they survive and optimally grow. Hence, on the basis of temperature values we can identify the thermophiles, i.e., microorganisms living at temperatures ranging from $60^{\circ} \mathrm{C}$ to $80{ }^{\circ} \mathrm{C}$; the hyperthermophiles, that live at $\mathrm{T}>80^{\circ} \mathrm{C}$; the psychrophiles, i.e., living at temperatures below $15^{\circ} \mathrm{C}$. On the basis of $\mathrm{pH}$ values, extremophiles are classified as acidophiles (living at $\mathrm{pH}<3$ ) or alkaliphiles (living at $\mathrm{pH}>9$ ). The bacterial species able to survive in the presence of high $\mathrm{NaCl}$ concentrations are the so-called halophiles; those living at low oxygen tension or in its total absence, are the microanaerobes and the anaerobes, respectively. The microorganisms able to survive to low water activity are defined as xerophiles. Finally, those microorganisms living under high pressure or in the presence of high radiations levels are defined as barophiles and radioresistant, respectively. Many extremophiles can also be defined as poly-extremophiles since some of them are actually able to simultaneously resist different extreme conditions, for example the thermoacidophilic bacteria that thrives at high temperature and low $\mathrm{pH}$; some species halophilic species that tolerate both high salt concentration and alkaline $\mathrm{pH}$; or finally some radioresistant species that resist also other extreme conditions like very low temperature, absence of water, and vacuum. Different kinds of extremophiles can be found in several marine ecosystems that are characterized by more than one extreme condition such as hypersaline habitats, high pressures, and extreme temperature. Some examples include the shallow vents, the submarine hydrothermal vents and the black smokers; the cold seas in both Arctic or Antarctic regions, the ocean depths and some hypersaline lakes of oceanic origin. Over the last few decades, the extremophiles have attracted a great deal of interest since they produce a wide array of biotechnologically useful molecules like the enzymes (also called extremozymes). Competition for space and nutrients in the marine environment constitutes a selective force leading to evolution and generating multiple enzyme systems to adapt to the different environments. Many marine extremophiles are capable of overcoming such extreme conditions and are a source of enzymes with special characteristics. Therefore, these microorganisms are of great interest for industrial processes, mainly in biocatalysis [3,4]. Metagenomic studies have revealed that extremophile prokaryotes from marine habitats are a source of novel genes and consequently a source of new bioproducts, including enzymes and other active metabolites. Therefore, it is important to study and understand these microorganisms in order to be able to use the biochemical, ecological, evolutionary, and industrial potential of these marine microbes $[5,6]$. This vast variation in marine habitats has led to the development of new hydrolases—such as proteases, lipases, glycoside hydrolases, etc.—with novel specificities and properties including tolerance to extreme conditions used in industrial processes $[7,8]$ Thanks to their peculiar features, the enzymes from marine extremophiles can be exploited for several industrial processes in the agricultural, chemical, food, textile, pharmaceutical, bioenergy, and cosmetic fields. Indeed, extremozymes are active at the harsh $\mathrm{pH}$, temperature, and pressure conditions typical of many industrial environments. For these reasons, their application enables the implementation of new biotechnologies that are the key approach to a more sustainable industrial system. Therefore, the variety of marine ecosystems in which extremophiles can be found represent an interesting source of industrially useful for manifold applications. With the advent of biotechnology, enzymatic engineering, and the introduction of other innovative technologies, it is possible to achieve efficient management of our rich marine microbial biodiversity towards the creation of new enzymes that could be recovered from marine microorganisms and efficiently exploited, not only as a cost effective biocatalyst but also as an ecofriendly reagent in the coming years. Considering the enormous microbial diversity native to the vast marine environments of this planet earth, efforts channeled into the discovery of new enzymes from marine microbes are inadequate and justify the launch of intensive screening programs 
by scientists globally. Such a mammoth attempt alone can return a large number of new enzymes for various human purposes and services, for the simple reason that marine environments are rich in new enzymes that probably could also avoid the need for enzymatic engineering or molecular cloning to design new enzymes for specific needs. In the long term, probably, processes based on marine microbial enzymes will replace many of the current chemical processes [4].
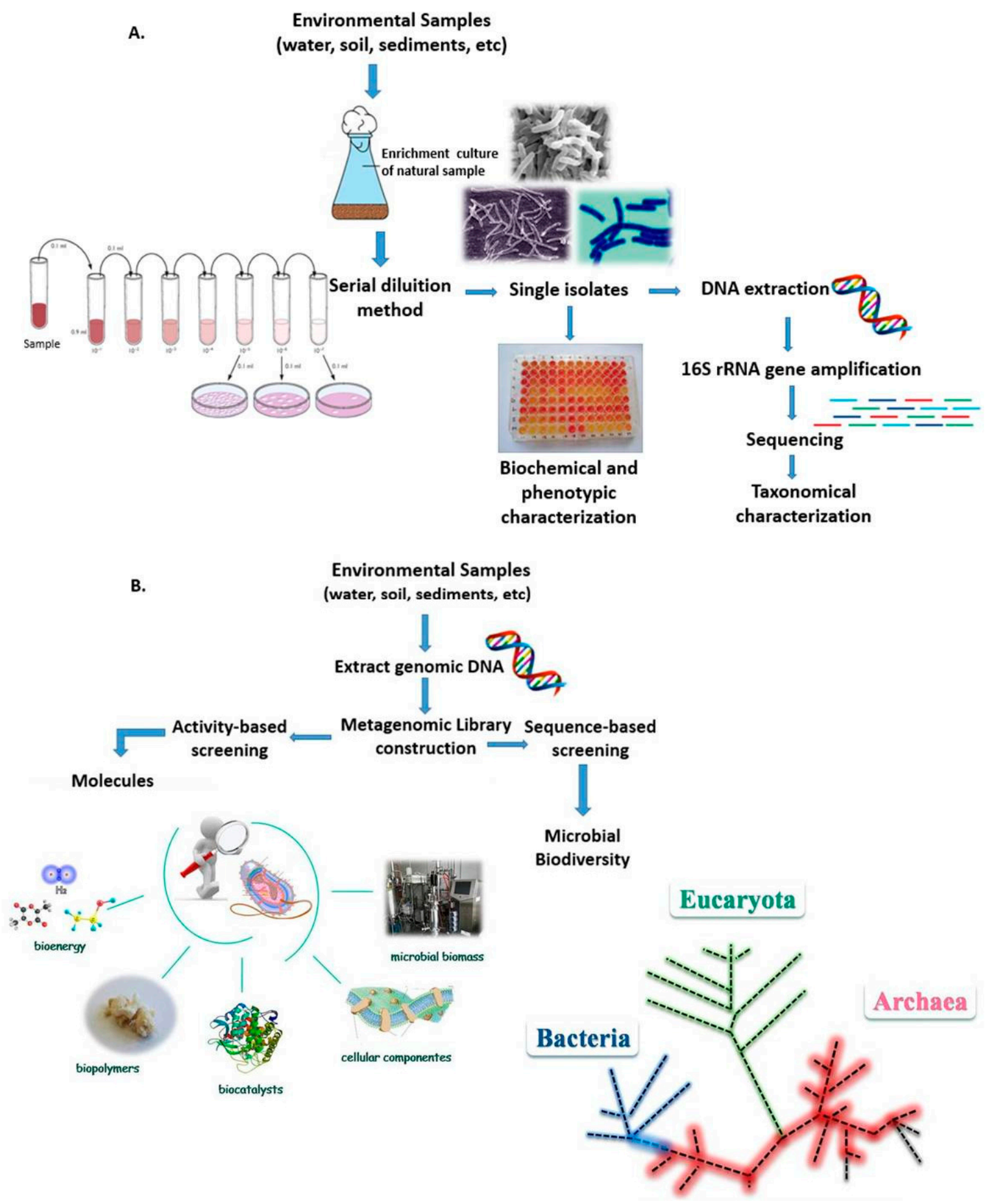

Figure 1. Microbial diversity studies. (A) Cultivation-dependent approach: scheme of a traditional isolation of strains through serial dilution method and their genetic, phenotypic and biochemical studies for microbial characterization; (B) Metagenomic approach: scheme of a metagenomic library construction with identification of molecules (activity-screening) and microbial communities (sequence-based screening). 
In the following section, we will give an overview of the main marine extremophiles and of the environments in which they are found, of the actual or possible industrial applications of marine extremozymes and finally of the strategies to identify new interesting species based on identification of new sampling sites.

\section{Extreme Ecosystems}

The biodiversity of ecosystems is a subject of intensive study; consequently, an affluence of information has been gathered on the distribution of microorganisms in the world. In addition, there is a growing interest about the role of marine microorganisms in biogeochemical processes, biotechnology, pollution, and pharmaceutical fields. In recent years, many authors have focused on the potential of marine microorganisms as prolific producers of bioactive substances and exploiting the vast marine microbial treasure for their utilization as novel drug delivery systems [9]. Extremophilic microorganisms are in several extreme marine environments, such as hydrothermal vents, hot springs, salty lakes, and deep-sea floors. The ability of these microorganisms to support extremes of temperature, salinity, and pressure demonstrates their great potential for biotechnological processes. Several different extreme environments, characterized by geochemical and physical extremes, are found in the ocean and in seas and many of them appeared to be hot spots for microbial abundance and diversity, thanks to the overwhelming presence of substrates and energy sources that support microbial metabolism. The most studied extreme oceanic environments are the vent ecosystems, such as the hot deep-sea hydrothermal vents (DSHVs) or cold seeps and mud volcanoes, and the hypersaline ecosystems such as the deep anoxic hypersaline lakes, brine lakes on mud volcanoes, and brines contained within sea ice. However, new fascinating extreme habitats for microbial life in the ocean are being discovered continuously such as water droplets entrapped in oil deposits. These environments comprise a large variety of extreme physicochemical conditions, which contribute importantly to the composition and shaping of the residing microbial communities and select for extremophile populations of microorganisms. These polyextremophiles are the key players of the element cycles in these environments, often responsible for primary productivity and endemic [10]. The development of more automated and affordable techniques for isolating and characterizing marine microbial bioactive metabolites, make marine products more accessible. Actually, the marine habitat represents the most studied environment for the richness related to the diversity of microorganisms and for the potential source of molecules possessing biological activities [9]. In particular, extreme marine environments constitute peculiar ecological niches in which extremophiles thrive developing unique biochemical strategies and features of industrial interest. The first studies on extremophiles from extreme habitats based on strains isolation using classic culture-dependent approaches (Figure 1A). With this method, only microorganisms whose metabolic and physiological requirements can be duplicated in the laboratory could be isolated. To overcome this limitation related to culture-dependent method, recently metagenomic approaches have been developed in order to explore and to access the uncultured microbial community (Figure 1B).

\subsection{Cold Environments}

Psychrophiles are extremophilic bacteria or archaea which are cold-loving, having an optimal temperature for growth at about $15^{\circ} \mathrm{C}$ or lower, a maximal temperature for growth at about $20^{\circ} \mathrm{C}$ and a minimal temperature for growth at $0^{\circ} \mathrm{C}$ or lower. Psychrotrophs, also termed psychrotolerant, are cold-tolerant bacteria or archaea that have the ability to grow at low temperatures, but have optimal and maximal growth temperatures above $15^{\circ} \mathrm{C}$ and $20^{\circ} \mathrm{C}$, respectively. Most of the Earth's biosphere is cold. Approximately $14 \%$ of the Earth's surface is in the polar region, whereas $71 \%$ is marine. By volume, more than $90 \%$ of the ocean is $5^{\circ} \mathrm{C}$ or colder. Below the thermocline, the ocean maintains a constant temperature, a maximum of $4-5{ }^{\circ} \mathrm{C}$, regardless of latitude. Therefore, all pressure-loving microorganisms (i.e., barophiles) are either psychrophilic or psychrotrophic and this is to be expected because the water below the thermocline of the ocean is under hydrostatic pressure. Moyer and 
Morita [11] underlined the importance to take environmental samples where the in-situ temperature never exceeds the psychrophilic range and to ensure that the growth medium, pipettes, inoculating loops, etc. are kept cold before use. This could explain why early microbiologists failed to isolate psychrophiles. Even if the term psychrophiles was first reported in 1884, most of the early literature actually dealt with psychrotrophic bacteria and not with true psychrophiles. Since investigators were not working with extreme cold-loving bacteria, there was much debate and, as a result, many terms were coined to designate psychrophiles such as cryophile, psychrorobe, facultative psychrophile, psychrocartericus, psychrotrophic, and psychrotolerant [11]. The Antarctic marine environments for example are characterized by an average temperature of about $-1{ }^{\circ} \mathrm{C}$. This low temperature produces two main physicochemical effects: the rate of chemical reactions decreases exponentially according to the Arrhenius law and strong effect on the viscosity of the medium, thereby contributing to further slow-down reaction rates. The Antarctic continent, considered as an uncontaminated site, is unfortunately experiencing increasing contaminant influxes that are likely to become more severe in the future. Heavy metals have been mainly detected in the $2 \%$ of ice-free lands of the continent, where most of the human activities occur in different areas, including Terra Nova Bay in addition to the concentrations accumulated in the biota [12]. Currently, the Arctic sea ice bacterium Psychromonas ingrahamii has demonstrated the lowest growth temperature $\left(-12^{\circ} \mathrm{C}\right)$ of any organism authenticated by a growth curve [13]. The first and only truly psychrophilic archaeon to be isolated is Methanogenium frigidum, a methanogen from Ace Lake, Antarctica [14]. Taxonomically, cold-loving microbes are found both in Archaea and Eucarya domains; they have been found in free or associated form with sponges for example, and distributed in numerous genera such as Arthrobacter, Colwellia, Exiguobacterium, Gelidibacter, Glaciecola, Halobacillus, Halomonas, Hyphomonas, Listeria, Marinobacter, Methanococcoides, Methanogenium, Moritella, Planococcus, Pseudoalteromonas, Pseudomonas, Psychrobacter, Psychroflexus, Psychromonas, Psychroserpens, Shewanella and Sphingomonas $[9,15,16]$. In order to understand the adaptation of psychrophiles to these extreme environments, their enzymes should be isolated, cloned, and characterized to gain further insight into their biotechnological potential. The first genomes studied were that of Colwellia psychrerythraea from Arctic marine sediments [17] and Pseudoalteromonas haloplanktis from Antarctic seawaters [18]. Nowadays, many genomes are available for a wide range of psychrophilic bacteria and archaea. As of early 2017, approximately 130 cold-adapted species have genome sequences [19]. Trait surveys, limited to the perspective of gene gain, reveal prevalence of genes demonstratively providing better growth at low temperature including compatible solute uptake and synthesis, antifreeze proteins and polyunsaturated fatty acids. This includes the presence of anti-freeze DUF3494-type proteins that occur in all domains of life but is limited to cold-adapted taxa and is absent in higher-temperature adapted life [19]. Among these adaptations, the factors responsible for the adjustment of membrane fluidity are of prime importance, whereas the large diversity of factors contributing to limit the toxicity of highly concentrated dissolved oxygen has been already investigated. These studies indicate a high content of enzymes involved in oxygen consumption such as desaturases, superoxide dismutases, and catalases whereas an unusual feature observed in the Antarctic Pseudoalteromonas haloplanktis is the elimination of the ubiquitous molybdopterin-dependent metabolism which is usually responsible for the production of reactive oxygen species. Nevertheless, further genome sequences are needed to detect whether there are some general trends in cold-adaptation or, if on the contrary, each microorganism has its own specific strategy. Proteomic analyses are also progressing and are required to establish the relationships that should exist between the expression of regulatory proteins and the environmental temperature [19].

\subsection{Hydrothermal Vent Habitats}

Hydrothermal vent fields occur mainly along the boundaries of tectonic plates, in regions known as mid-ocean ridge ranges, $90 \%$ of which are under the ocean, such as the East Pacific Rise and the Mid-Atlantic Ridge. Mid-ocean ridges are the sites of oceanic spreading centers, where magma rises from the mantle forming new crust as it cools and spreads away from the ridge. For the first time, 
by the submersible Alvin, at a depth of $2500 \mathrm{~m}$ on the Galapagos Rift of the Pacific Ocean, the chimneys were seen, from which black water at a temperature of about $300{ }^{\circ} \mathrm{C}$ and saturated with minerals shot out (Martin et al., 2008). These hydrothermal vent, called black smoker, located on the basaltic rock bottom and originating from fresh lava flows, were chemically reactive environments able to support suitable conditions for sustained prebiotic synthesis. The hot fluid is acidic, anoxic, rich in $\mathrm{Fe}, \mathrm{Mn}$, $\mathrm{Cu}, \mathrm{Zn}, \mathrm{Ba}$ etc., and poor in magnesium, nitrates, and phosphates. Volatile compounds from magma $\left(\mathrm{H}_{2} \mathrm{~S}, \mathrm{CO}_{2}, \mathrm{CH}_{4}, \mathrm{H}_{2}\right)$ may be added, further modifying the fluid composition [20]. The conditions around the vent systems can change quite rapidly with spreading rates changing the size of the edifices and ecology. Shallow water submarine hydrothermal vents represent easily accessible natural systems. Venting is well known off volcanic islands and provinces and are commonly detected by the presence of streams of gas bubbles. Deep-sea vents $(>200 \mathrm{~m})$ and shallow-water vents $(<200 \mathrm{~m})$ differ in community structure (in deep-sea dominance of symbiotrophic forms and in shallow-water a higher ratio of vent obligate taxa), composition, and environmental parameters. The temperature of fluids in shallow water vents is between 10 and $119^{\circ} \mathrm{C}$ whereas sediments can reach up to $95.8^{\circ} \mathrm{C}$, both light and hydrothermal energy support a complex microbial community [21]. At shallow depths hydrothermal vents lack the typically sulphide structures with some exceptions; fluid with lower concentrations of $\mathrm{CH}_{4}$ and $\mathrm{H}_{2}$ with respect to deep-sea vents, are enriched in $\mathrm{N}, \mathrm{P}$, and $\mathrm{Si}$. Thermophilic and hyperthermophilic Archaea and Bacteria are a common feature in these sites and more than 35 species have been found at west Pacific and Mediterranean vents. Coastal zones of the Southern Tyrrhenian Sea (Flegrean area, Cape Palinuro, Eolian Islands) represent easily accessible vents by diving. Analysis using Fluorescent in Situ Hybridization molecular and DGGE technique found that bacterial richness and biodiversity at two Volcano vents are greater than archeabacteria [22]. Pyrococcus, Thermotoga, Thermococcus, Archeoaglobus, Methanococcus, Pyrodictium, Aquifex and Igneococcus thrive in both shallow-water and in deep-sea hydrothermal systems. Members of Thermococcus (T. celer and T. litoralis) have been isolated from coastal hydrothermal systems [9]. In 2000, during a National Science Foundation expedition in the Mid Atlantic Ocean Zone $30^{\circ} \mathrm{N}$, a new type of vent system, named The Lost City hydrothermal field, was discovered. This vent system is one of the best examples of serpentinization processes in a marine environment [23]. The fluids venting in the Lost City chimneys range in temperature from $40^{\circ} \mathrm{C}$ to $90^{\circ} \mathrm{C}$ and are highly alkaline ( $\mathrm{pH}$ 9-11), with high concentration of dissolved $\mathrm{H}_{2}, \mathrm{CH}_{4}$, low molecular weight hydrocarbons but almost no dissolved $\mathrm{CO}_{2}$. These characteristics and extreme conditions are the result of chemo- and biosynthetic reactions. The production of fluids enriched in $\mathrm{CH}_{4}$ and $\mathrm{H}_{2}$ during serpentinization suggest that geochemical and geological processes should be support by moderately thermophilic as well as sulfate-reducing bacteria [24]. Deep-sea hydrothermal vents are unique environments that provide partial or complete energy/nutrient fluxes necessary to support diverse microbial communities that are distributed along the temperature range and reduced compound gradients more or less correlated with the transition from anoxic to oxic conditions. The large population of animals that surround the volcanically driven warm vents (mainly tubeworm communities and an array of crabs, shrimp, giant clam, and gastropods) is supported by the growth of chemoautotrophic microorganisms. These bacteria are the bases of the hydrothermal trophic food chain and they can exist: free-living associated with the dismissed vent fluids and probably growing and reproducing within the sub-seabed system, free-living microbial carpets growing on the surface exposed to flowing vent waters, through endo- and exosymbiotic associations with invertebrates, and within the deep sea hydrothermal vent plumes [25]. The most-studied physical and chemical parameter that limits microbial life is the temperature, indeed Bacteria and Archaea from hydrothermal vents have been extensively investigated in smoker fluids, black smoker sulfides and sediments that have higher temperatures [26] in order to hypothesize and speculate on the origin of life. The main bacterial species isolated and that grow at strict anaerobic and extreme temperature conditions belong to the Archaea kingdom: euryarchaeota and crenarchaeota. Euryarchaeota include methanogens (Methanococcus, Methanopyrus), and sulfate and iron-reducers (Archaeoglobus), whereas crenarchaeota include 
thermophilic and hyperthermophilic heterotrophs (Hyperthermus, Thermococcus, Staphylothermus, Pyrococcus, Desulforococcus). Most of the heterotrophic species exhibit maximal growth temperatures less than $105^{\circ} \mathrm{C}$, while Pyrodictium and the methanogen Methanopyrus species grow at $110{ }^{\circ} \mathrm{C}$, Pyrolobus fumarii at $113^{\circ} \mathrm{C}$ and strain 121 (member of the Desulfurococcales) at $121^{\circ} \mathrm{C}$ [9]. In The Lost City hydrothermal areas, the porous walls of the structures host hyperthermophilic, thermophilic and mesophilic bacteria. A methane-metabolizing Archaea related to the Methanosarcinales, growing at $80^{\circ} \mathrm{C}$, is the predominant group that thrive in these edifices, forming biofilms of about $10 \mathrm{~cm}$ thickness, adjoining to hydrothermal flow. Within the bacterial domain, cultured and identified thermophilic microorganisms make up a short list with respect to the domain Archaea. The thermophilic Eubacteria most frequently isolated in a deep-sea chimney belong to the orders Thermales, Aquificales and Bacillales; the main genera, Thermotoga and Desulforobacterium, sulphur-reducing, thermophilic, anaerobic and strictly autotrophic, grow at the temperature range of the $60-80^{\circ} \mathrm{C}$. Thermus and Bacillus thermophilic are heterotrophic aerobes and grow at the range of $60-75^{\circ} \mathrm{C}$. Representative species assigned to the order Thermotogales are Thermotoga maritima, Thermotoga neapolitana, Thermoanaerobacter ethanolics, Thermosipho melansiesis.

\subsection{Hypersaline Environments}

Hypersaline environments are extreme habitats where the salinity is much higher than that of seawater and depending on whether they are originated from seawater or not, can be divided into two main types of environments, thalassolohaline and athalassohaline, respectively. Examples of thalassohaline environments, concentrated salt solutions (brines), are some lakes, such as the Great Salt Lake in Utah, marine ponds and salt marshes subject to evaporation for high temperature. Salt marshes can be found in inland areas and coastal (marine) marshes occur in sheltered sites (frequently estuaries) where wave action is slight and deposition of silt allows higher plant to root. The estuaries exposed to intensive evaporation can also become extremely saline [27]. Human activity also creates highly saline habitats such as solar salterns (used for the production of salt by evaporation of seawater), which may have a $\mathrm{NaCl}$ concentration at saturation in some ponds [28]. Chemically, thalassohaline environments are characterized by a clear predominance of $\mathrm{Cl}^{-}$and $\mathrm{Na}^{+}$(responsible for $49 \%$ and $42 \%$ of the total molarity, respectively). Other important ions are $\mathrm{Mg}^{2+}, \mathrm{SO}_{4}{ }^{2-}, \mathrm{K}^{+}, \mathrm{Br}^{-}, \mathrm{HCO}_{3}{ }^{-}$, and $\mathrm{F}^{-}$. The average salinity of seawater is $3.5 \%$; when it concentrates (as in a solar saltern) its composition changes due to the serial precipitations. The class of extremophilic microorganisms specialized for living in extreme hypersaline environments, are designated as halophiles. Different authors use different definitions for what constitutes a halophile; the most popular definition of halophiles identifies microorganisms which grow optimally at $\mathrm{Na}^{+}$concentrations greater than $0.2 \mathrm{M}$. According to the optimal salt concentration for growth, they are classified in three categories: extreme halophiles, that grow in an environment with $3.4-5.1 \mathrm{M}(20 \%$ to $30 \%, w / v) \mathrm{NaCl}$; moderate halophiles, that grow in an environment with $0.85-3.4 \mathrm{M}(3 \%$ to $25 \%, w / v) \mathrm{NaCl}$; slightly halophiles that grow in an environment with $0.2-0.85$ $\mathrm{M}(1 \%$ to $5 \%, w / v) \mathrm{NaCl}$. Halotolerant microorganisms do not show an absolute requirement for salt but grow well in high salt concentrations [29]. Marine salterns are habitats for a large variety of halophilic or halotolerant bacteria that develop throughout the entire gradient of salt concentration [30]. In the first ponds most bacteria are slightly halophilic, whereas in the intermediary ponds, where the seawater is concentrated to a salinity of about 10 to $20 \% \mathrm{NaCl}$, most of the bacteria are moderately halophilic. This intermediate environment contains the greatest numbers of organisms. The last ponds are inhabited by extremely halophilic organisms including aerobic members of the Archaea belong to the genera Halobacterium, Natronobacterium, Haloferax and Haloarcula in addition to several species pertaining to the Bacteria and Eucarya. Only one methanogenic species of the Archaea was reported to grow optimally at $\mathrm{NaCl}$ concentrations over $20 \%$ [28]. Halophiles have developed different adaptive strategies to support the osmotic pressure induced by the high $\mathrm{NaCl}$ concentrations. Some extremely halophilic bacteria accumulate inorganic ions $\left(\mathrm{K}^{+}, \mathrm{Na}^{+}, \mathrm{Cl}^{-}\right)$in the cytoplasm, which is a type of 'salt-in' strategy to balance the osmotic pressure of the environment. Moreover, they have also 
developed specific proteins that are stable and active in the presence of salts [31-35]. The halophilic microorganisms contain enzymes that maintain their activity at high salt concentrations, alkaline $\mathrm{pH}$ and high temperatures. The stability of the enzymes depends on the negative charge on the surface of the protein due to acidic amino acids, the hydrophobic groups in the presence of high salt concentrations and the hydration of the protein surface due to carboxylic groups present in aspartic and glutamic acids. In addition, negative surface charges are thought to be important for the solvation of halophilic proteins, to prevent denaturation, aggregation, and precipitation [36].

\section{Marine Extremozymes: Current and Potential Applications for Biofuels Production and Bioremediation Processes}

The development of the modern biotechnology has generated an increasing request for enzymes with novel properties for multiple industrial processes. Extremozymes are produced by bacteria that have adapted to harsh environmental conditions, like extreme temperature and $\mathrm{pH}$ variations, high salt concentration and pressure. Therefore, extremozymes are quite attractive because they are more resistant when compared to the terrestrial mesophilic homologs. Indeed, their peculiar features make them suitable for different biotechnological applications [36]: in this section, attention is paid to the exploitation of extremozymes for the production of renewable energy and the bioremediation of polluted sites.

The green biotechnology for the sustainable production of bioenergy can take advantages from marine extremozymes that indeed can be useful for the production of biofuels like bioethanol, biodiesel, and biohydrogen [37]: some remarkable examples are reported in Table 1.

Table 1. Marine enzymes for biofuels production.

\begin{tabular}{cccc}
\hline Source & Enzyme & Application & Ref. \\
\hline Thermococcus sp. & Amylase (Fuelzyme®) & 1G-Bioethanol production & {$[36]$} \\
\hline Bacillus carboniphilus CAS 3 & Cellulase & & {$[38]$} \\
$\begin{array}{c}\text { B. subtilis subsp. subtilis A-53 } \\
\text { Bacillus licheniformis AU01 }\end{array}$ Carboxymethylcellulase & 2G-Bioethanol production & {$[39]$} \\
G. thermoleovorans IT-08 & Cellulase & {$[40]$} & {$[41]$} \\
\hline Bacillus sp. H1666 & Cellulase & & {$[42]$} \\
Cobetia sp. NAP1 & Cellulase & 3G-Bioethanol production & {$[43]$} \\
Exiguobacterium sp. Alg-S5 & Alginate lyase and cellulase & & {$[44]$} \\
Microbulbifer thermotolerans & Agarase & & {$[45]$} \\
JAMB-A94 & & & {$[46]$} \\
\hline Aeromonas sp. EBB-1 & Biodiesel production & {$[47]$} \\
Candida antarctica & Lipase & Biohydrogen production & {$[48]$} \\
\hline Photobacterium lipolyticum & & & {$[49]$} \\
\hline Catenovulum sp. X3 & Amylase & & \\
\hline
\end{tabular}

Bioethanol production from starchy materials, the so-called first generation (1G) bioethanol, is a consolidated industrial process in those countries using it as a transportation fuel, like USA and Brazil. The conversion of starchy materials in glucose is catalyzed by amylases, particularly by thermostable amylases that allow to accelerate the conversion rates with low risks of contamination. Different commercial amylases are available, like the alpha-amylase produced by a Thermococcus sp. isolated from a deep-sea hydrothermal vents. The latter is commercialized as Fuelzyme ${ }^{\circledR}$ —Verenium Corporation (San Diego, CA, USA) and it is usually exploited for the mash liquefaction, the first step of starchy biomass conversion [36].

The concerns about bioethanol production due to its impact on food chain, in recent years, has driven the search for a more sustainable production of bioethanol based on non-food biomass like the lignocellulosic or the algal biomass. The enzymes from marine extreme bacteria are among the most promising biocatalysts, since they are resistant to temperature, salt concentration and contaminants. The production of bioethanol from lignocellulosic biomass, the so-called second generation bioethanol (2G-bioethanol), relies on the exploitation of cellulase and xylanase enzymes. The bacterium Bacillus carboniphilus CAS 3, a species isolated from marine sediments collected from Parangipettai coast in 
India, has shown to be a cellulase activity producer. Its cellulase activity has been shown to carry out an extensive saccharification of pretreated rice straw, yielding about $15.56 \mathrm{~g} / \mathrm{L}$ of reducing sugar after $96 \mathrm{~h}$ [38]. The species Bacillus subtilis subsp. subtilis A-53, isolated from seawater of the seashore in the Kyungsang (Korea), produces a carboxymethylcellulase that is a salt tolerant enzyme able to hydrolyze cellulosic materials in the typical severe conditions of the industrial conversion of biomass to fermentable sugars [39]. Bacillus licheniformis AU01, a species isolated from marine sediments in India, is able to produce a cellulose enzyme by using cellulosic wastes as carbon sources. The cellulase purified from this bacterium is thermostable and resists high $\mathrm{pHs}$ and several types of detergents, thus it could be useful for hydrolysis of lignocellulosic materials for ethanol production [40]. The species xylanase activity from Geobacillus thermoleovorans IT-08, isolated from a hot spring in Indonesia, has been investigated for its application in lignocellulose degradation. After expression in Escherichia coli DH5, the xylanase has been used for the hydrolysis of corncob and oat spelt xylan: this enzyme is able to degrade insoluble lignocellulosic materials to produce xylooligosaccharides and monomer sugars (xylose and arabinose) to be fermented to ethanol [41].

The production of third generation bioethanol (3G-bioethanol)-i.e., bioethanol from algal biomass-is receiving growing interest in relation to the search for more sustainable processes of renewable energy production. Algae store carbohydrates mainly as agarose, but also in the form of starch or cellulose, whose conversion to fermentable sugars is of interest in relation to the production of biofuels. The biotransformation of algal biomass to fermentable sugars is carried out by means of cellulose, agarose, and alginate lyase enzymes. Some recent examples of marine enzymes for 3G processes include the cellulase activity from Bacillus sp. H1666, whose applicability was tested on dried green seaweed (Ulva lactuca). The saccharification of the algal biomass by means of this enzyme was carried out in a single step processes, affording an increase of $450 \mathrm{mg} / \mathrm{g}$ in glucose yield [42]. The bacterium Cobetia sp. NAP1, isolated from the brown algae Padina arborescens Holmes, produces an alginate lyase (AlgCPL7) whose optimal temperature and $\mathrm{pH}$ are $45^{\circ} \mathrm{C}$ and 8 , respectively. This enzyme is thermostable and salt tolerant, is promising for the production of biofuels since it afforded high yields of alginate's degradation [43]. The species Exiguobacterium sp. Alg-S5 is the first example of bacterium able to co-produce alginate lyase and cellulase enzymes. These enzymes have been showed to be of potential application for the bioconversion of alginate and cellulose containing wastes into value-added products and biofuels [44]. The deep-sea bacterium Microbulbifer thermotolerans JAMB-A94 produces an endo- $\beta$-agarase that has been modified by fusion with a carbohydrate-binding module (CBM) derived from the species Catenovulum agarivorans. The fusion resulted in a significant agar depolymerisation $(45.3 \%$, with a reducing sugar yield of $14.2 \%$ ) that showed the potential application of tis enzyme for a new enzymatic prehydrolysis process for the saccharification of agar, a major component of red algal biomass, one of the main feedstocks for 3G bioethanol production [45].

Marine extremozymes find applications also for the production of other alternative fuels like biodiesel and biohydrogen. Biodiesel is produced via alcohol transesterification of oils of vegetable or animal sources, catalyzed by lipase enzymes. A thermophilic lipase is produced by Aeromonas sp. EBB-1, isolated from marine sludge in Thailand: this enzyme is stable at $\mathrm{pH} 6.0-8.0$ and $\mathrm{T} 30-80{ }^{\circ} \mathrm{C}$, and is very active in the hydrolysis of long chain esters, thus being a promising and robust biocatalyst for industrial applications [46]. An industrially relevant lipase of marine bacterial origin is represented by lipase B from Candida antarctica (Novozym435). In a recent study, the lipase B, immobilized by means of functionalized nanoparticles was used to generate biodiesel from waste cooking oil. The immobilized preparation of the enzyme enhanced the reusability of the enzyme, that indeed kept $100 \%$ of its starting activity after six cycles of the reaction [47]. Lipases can undergo loss of activity in the presence of high concentrations of methanol, usually required for the efficient production of biodiesel. A methanol-tolerant lipase is produced by Photobacterium lipolyticum: this enzyme was tested with waste oil and olive oil, and it proved to be very effective also in the presence of either water or high alcohol concentrations, achieving a biodiesel yield of about the $70 \%$ of the possible maximum yield [48]. Amylases from marine bacteria have been tested for the production of biohydrogen, a biofuel produced 
by fermentation of carbohydrate-rich biomass like starch. The marine bacterial strain Catenovulum sp. $\mathrm{X} 3$, isolated from seawater in China, produces an interesting amylase enzyme that is active at alkaline $\mathrm{pHs}$ and in the presence of organic solvents. This enzyme was used to produce fermentable sugars for Clostridium species, and it allowed to gain a 3.73-fold higher yields of biohydrogen production [49].

The extremozymes of marine origin have proved to be useful also for bioremediation applications. Different kinds of wastes and contaminants are produced from the industrial activities, the mining activities for oils extraction or the accidental oil spills. All these activities release in the marine environments several pollutants like hydrocarbons, polycyclic aromatic hydrocarbons, chlorinated hydrocarbons, pesticides, heavy metals, etc. [50]. The removal and detoxification of these contaminants and wastes can be achieved by means of extremozymes: some examples are listed in Table 2.

Table 2. Marine enzymes for bioremediation processes.

\begin{tabular}{cccc}
\hline Source & Enzyme & Application & Ref. \\
\hline Bacillus safensis (CFA-06) & Oxidoreductase & Biodegradation of aromatic compounds & [51] \\
\hline Marine metagenome & Laccase & Degradation of industrial dyes & [52] \\
\hline Alcanivorax borkumensis SK2T & Alkane hydroxylases/Cytochrome & Degradation of alkanes \\
Alcanivorax dieselolei B-5T & P450 & & \\
Alcanivorax venustensis ISO4T & & \\
Bacillus licheniformis ATCC 14580T & & \\
Bacillus litoralis DSM 16303T & & \\
Bacillus oshimensis JCM & & & \\
Halomonas ventosae Al12T & & Degradation of PAH \\
Idiomarina baltica DSM 15154T & Dioxygenase & [53] \\
\hline Nocardioides sp. strain KP7 & Degradation of halogenated pollutants \\
\hline Pseudomonas stutzeri DEH130 & [55,56] \\
Paracoccus sp. DEH99 & & & [57] \\
Psychromonas ingrahamii & & & [59] \\
Alcanivorax dieselolei strain B-5 & & & \\
\hline
\end{tabular}

Legend. PAH, polycyclic aromatic hydrocarbons.

The oxidoreductases are a group of enzymes that display a potential role for bioremediation of dyes, the main contaminants released by the textile industry. The bacterial species Bacillus safensis (CFA-06), isolated from petroleum in Campos Basin (Brazil) produces two oxidoreductases, a catalase and a new oxidoreductase. The two enzymes showed to be very active in the degradation of aromatic hydrocarbons thus suggesting promising application for petroleum removal [51]. Another interesting group of marine bacterial oxidoreductases is represented by the laccases-i.e., those enzymes able to catalyze the oxidation of phenolic and non-phenolic aromatic compounds. Such enzymes find manifold applications in bioremediation of textile dyes or as biosensors. Recently, a bacterial laccase gene (lac21) was screened by a metagenomic approach from a marine library: this enzyme showed unusual properties like high stability at $40{ }^{\circ} \mathrm{C}$, for pHs ranging from 5.5 to 9.0; high activity in the presence of chloride, high decolorization capability toward azo dyes [52].

Natural oil seepage and oil spills are the main causes of hydrocarbons' contamination of marine environments. The biodegradation of these polluting agents can be carried out by marine microorganisms producing enzymes able to catalyze the oxidization of medium-length alkanes, like the non-haem diiron alkane hydroxylases (AlkA, AlkB) and the cytochrome P450 belonging to the CYP153 family. Several bacterial species belonging to many genera, have been isolated from marine environments as producers of alkane degrading enzymes: some remarkable examples of these enzymes and of their producers are listed in Table 2 [53] The degradation of aromatic compounds is another key issue in bioremediation of oil contaminated sites: the species Nocardioides sp. strain KP7, isolated from a Kuwait beach, produces a dioxygenase that is able to degrade phenanthrene and that has been identified thanks to its detoxification action after an oil spill accident [54]. Numerous marine species have been identified as producers of enzymes catalyzing the degradation of halogenated compounds that have a significantly negative impact on the health and the environment [55]. Some interesting haloacid dehalogenases-i.e., enzymes able to catalyze the de-halogenation of 2-alkanoic acids-have 
been isolated from the marine bacterium Pseudomonas stutzeri DEH130 [56] and from Paracoccus sp. DEH99 [57]. The bacterium Psychromonas ingrahamii, isolated from the sea ice interface, has been described as a producer of a haloacid dehalogenase active against chlorinated and brominated short chain $(<\mathrm{C} 3)$ haloacids $[55,58]$. Alcanivorax dieselolei strain B-5, isolated for the first time from surface water of the Bohai Sea, produces different alkane hydroxylase systems that enables it to degrade either chlorinated or brominated alkanes with different chain lengths, thus displaying an interesting potential for biodegradation and other industrial applications [59]

\section{Satellite Microwave Remote Sensing to Support the Identification of Potential Sampling Sites}

Remote sensing tools represent a key resource to identify potential sites harboring extremophiles and to support the planning of in-situ sampling campaign. Satellite remote sensing provides, in a cost-effective way, updated and synoptic maps of the oceans ensuring global coverage and sufficient revisit time. In most cases, in fact, the harsh conditions where extremophiles are present make very difficult to organize in-situ campaigns, while satellite remote sensing allows monitoring and exploring even unsafe and almost inaccessible areas-e.g., polar regions or polluted areas. Among the different remote sensing instruments actually operating from space, microwave sensors can provide information on the sea surface day- and night-time in almost any weather conditions and, therefore, represent the most suitable tool to identify potential sites for extremophiles' sampling. In this framework, both active and passive microwave remote sensing sensors can be exploited [60-62]. The formers are equipped with their own source of radiation, i.e., laser imaging detection and ranging (LiDAR) and synthetic aperture radar (SAR), while the latter only receive the radiation emitted by the Earth's surface in the microwave range of the electromagnetic spectrum, i.e., radiometer.

The always growing interest in the operational exploitation of satellite remote sensing data to monitor the oceans is witnessed by the European Space Agency (ESA) Sentinel-3 mission started in 2016 with the launch of the Sentinel-3A satellite and continued in 2018 with the launch of the Sentinel-3B one. This space mission represents a cutting-edge technology to monitor the oceans from space since it is equipped with a payload composed by four main sensors, namely the sea and land surface temperature radiometer (SLSTR), the ocean land and color instrument (OLCI), the SAR altimeter (SRAL), and the microwave radiometer (MRW) [63]. The Sentinel-3 mission, operated by EUMETSAT, represents, up to now, the most advanced ocean mission that aims at providing a comprehensive understanding of ocean processes taking full benefits by a synergistic approach that combines both active and passive remote sensing sensors covering a broad spectral range (including optical, near infrared, thermal infrared, and microwaves). In this framework, several operational high-quality products are delivered by the Sentinel-3 mission that include, but are not limited to, sea surface temperature (SST) and wind speed, significant wave height, sea ice concentration, and algal pigment concentration [64]. Nevertheless, in this study, only spaceborne microwave tools are addressed as a source of information for supporting the identification of potential extremophiles sites.

Nowadays, satellite microwave remote sensing sensors are currently exploited to deliver added-value products operationally. Spaceborne SAR measurements are used to monitor, on a local scale, critical infrastructures belonging to oil and gas companies, including rigs, drilling platforms, and pipelines, as well as polluted sea areas $[65,66]$. Satellite radiometers are used to monitor, on a global scale, sea surface parameters as temperature and salinity, as well as ice-covered sea areas $[67,68]$ In this study, a brief overview on the exploitation of satellite microwave remote sensing sensors to identify potential sites of extremophiles living in harsh environments is proposed. In this study, three different showcases are presented and discussed:

- Identification of oil-polluted sea surface areas by means of satellite polarimetric SARs.

- Identification of sea surface areas characterized by extreme temperature/salinity conditions by means of multi-frequency polarimetric radiometers.

- Identification of extreme ice-infested sea surface areas by means of single- and multi-frequency polarimetric radiometers. 
SARs measure, for each resolution cell, the associated normalized radar cross sections (NRCS). The latter is a measure of how much electric field is scattered off the elements within the resolution cell towards the SAR antenna. An example of NRCS measurements, collected on 5 February 2016 over the Ross Sea (Antarctica) by the C-band ( $5.4 \mathrm{GHz}$ ) polarimetric SAR on-board of the ESA Sentinel-1 mission is shown Figure 2.

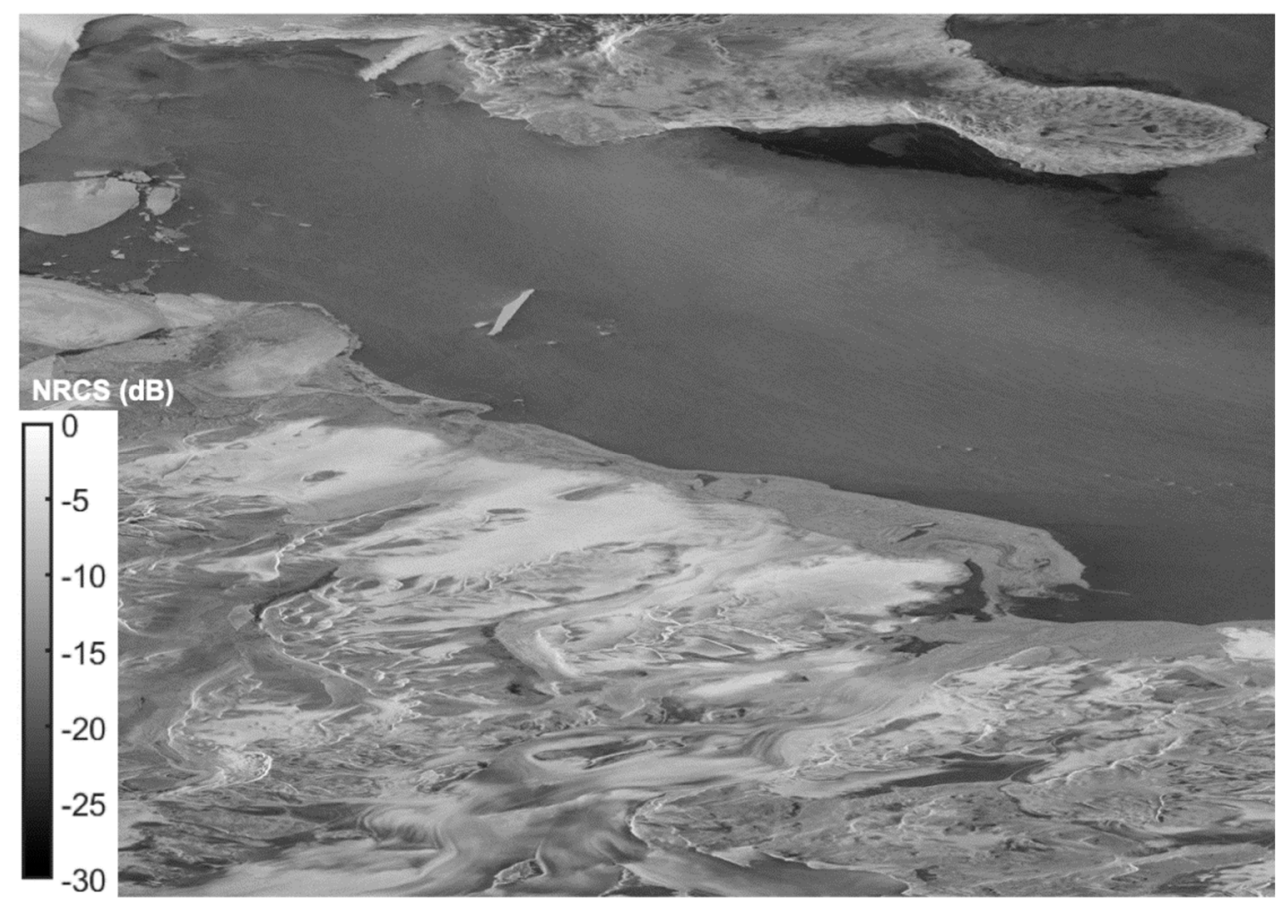

Figure 2. HH-polarized NRCS excerpt of a Sentinel-1 SAR image, shown in radar coordinates, collected on 5 February 2016 over the Ross Sea (Antarctica).

The SAR-based detection of polluted sea surface areas is possible since the presence of the oil layers over the ocean dampen the short gravity and capillary waves which, being resonant with the wavelength of the incident electromagnetic wave, are responsible of the backscattered NRCS measured by the SAR antenna. As a result, due to the oil damping properties that reduce the roughness of clean sea surface, the NRCS related to the oil slick is lower than the one coming from the surrounding sea, i.e., oil-affected sea areas appear as patches darker than the sea background in grey-tones intensity image. Nevertheless, there are several marine features that may call for similar dark patches over the sea surface, including low-wind areas, shadow regions, biogenic films, algal blooms, and other weak-damping surfactants which are all termed as oil look-alikes. However, it was widely demonstrated that polarimetric information allows significantly reducing false alarms due to oil look-alikes by exploiting the different scattering properties that characterize slick-free and oil slick-covered sea surface $[69,70]$. Among the several polarimetric features used to emphasize the presence of an oil slick with respect to the clean sea background in order to support oil-polluted sea area detection, the standard deviation (std) of the co-polarized phase difference (CPD) was shown to be very effective [71]. The latter provides a reliable estimation of the correlation between $\mathrm{HH}$ and VV backscattering channels (horizontally- and vertically-polarized transmitting/receiving electromagnetic wave). In fact, the large degree of correlation between co-polarized channels that characterizes clean sea surface scattering results in CPD std values lower than the corresponding ones that characterize the oil-polluted area calling for weak HH-VV correlation. As an example, Figure 3 shows the oil polluted sea areas identified by the X-band $(9.6 \mathrm{GHz})$ polarimetric SAR on-board of the German Aerospace Center (DLR) TerraSAR-X (TSX) mission, which provides NRCS measurements with 0.5 decibel (dB) 
radiometric sensitivity, in dual-polarimetric $\mathrm{HH}-\mathrm{VV}$ mode over an area of about $50 \times 30 \mathrm{~km}$, with approximately $3 \mathrm{~m}$ spatial resolution and an average revisit time of 4.5 days.

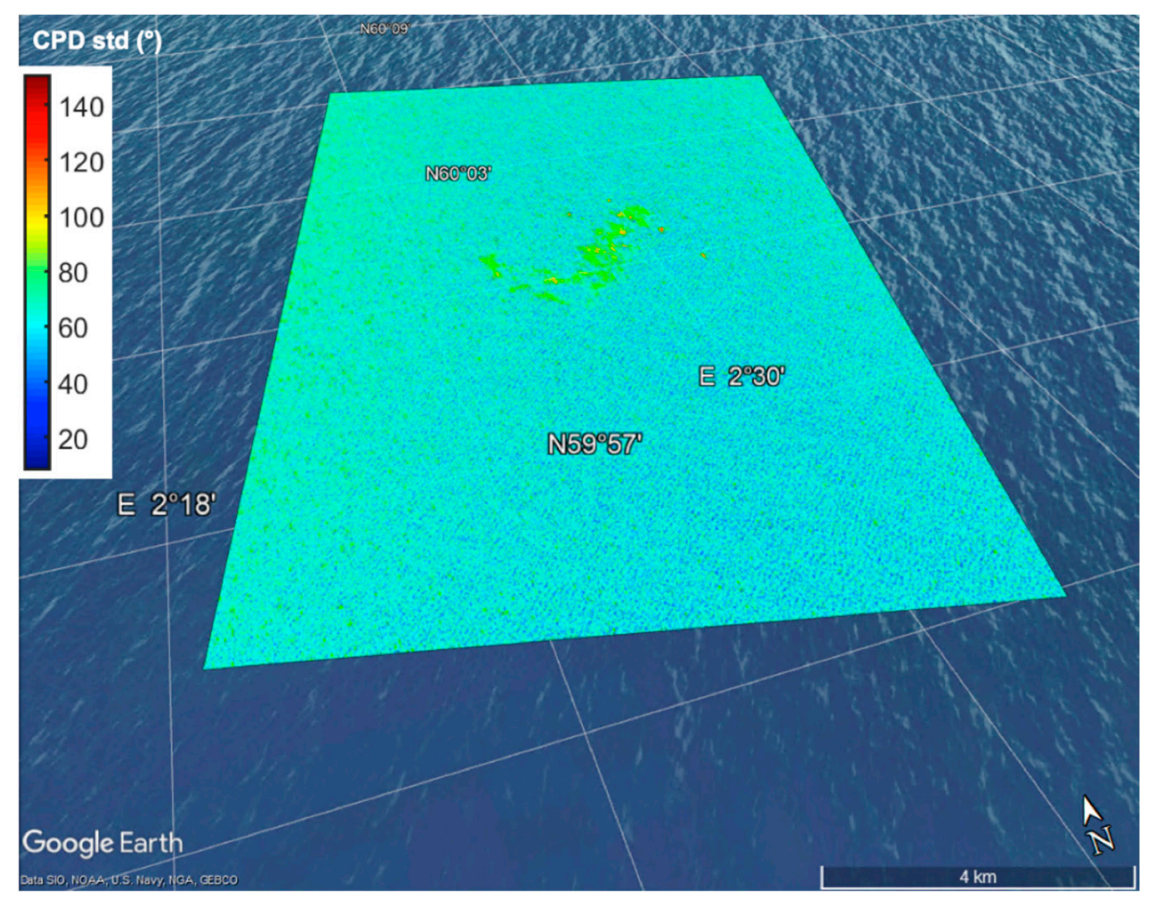

Figure 3. CPD std map obtained from the a TSX SAR scene collected on 8 June 2011 over an oil-polluted area off the southwestern coast of Norway and superimposed on a reference Google Earth optical image.

Two of the most important sea surface geophysical parameters useful for the identification of extremophiles are SST and sea surface salinity (SSS). Microwave radiometers equipped on-board of satellite platforms allow providing global information to identify sea surface areas calling for extreme SST and SSS values where thermophiles/hyperthermophiles and psychrophiles (SST larger than $60^{\circ}$ and lower than $15^{\circ} \mathrm{C}$, respectively), and halophiles (SSS $>30 \mathrm{psu}$ ) can be potentially found. They can be both retrieved from brightness temperatures (BT) measured from satellite microwave radiometers, that is a measurement of the radiance associated to the microwave radiation traveling upward from the top of the atmosphere to the radiometer antenna. An example of BT measurements, collected at $89.000 \mathrm{GHz}$ over the north Atlantic area by the advanced microwave scanning radiometer for EOS (AMSR-E) on-board of the National Aeronautics and Space Administration (NASA)/Japanese Aerospace eXploration Agency (JAXA) Aqua space mission on 2 July 2011 is shown Figure 4.

The derivation of SST standard products from microwave radiometers is possible since the intensity of the radiations naturally emitted by sea surface in the microwave range of the electromagnetic spectrum changes with temperature $[67,68]$. In fact, the V-polarized BT measured by microwave radiometers over ocean areas calls for significant sensitivity to SST, surface roughness, and atmospheric temperature. Nonetheless, the effects of the latter are removed exploiting the polarimetric and multi-frequency capabilities of the most up-to-date spaceborne radiometers. As an example, Figure 5 shows a global SST map on a $25 \mathrm{~km}$-grid obtained from AMSR-E measurements collected in the period 2-4 October 2011. AMSR-E provides multi-frequency $(6.925 \mathrm{GHz}, 10.650 \mathrm{GHz}$, 18.700 GHz, 23.800 GHz, 36.500 GHz, and 89.000 GHz) BT measurements, with 0.3-1.1 K radiometric sensitivity, a swath width of approximately $1445 \mathrm{~km}$, with about $6 \mathrm{~km} \times 4 \mathrm{~km}$ (at $89.000 \mathrm{GHz})$ to $75 \mathrm{~km} \times 43 \mathrm{~km}$ (at $6.925 \mathrm{GHz})$ spatial resolution on a daily basis. In Figure 5, it can be observed that the most promising sites for sampling extremophiles thermophiles and hyperthermophiles, i.e., sea areas characterized by extreme temperature values, are the polar regions, the Pacific coast of Mexico, the Gulf of Mexico and the Caribbean Sea, the Red Sea and the Gulf of Aden, the coasts of India, and the Arabian Sea. 
The derivation of SSS standard products from microwave radiometers is possible since the microwave radiation emitted by sea surface is partly dependent on the electric permittivity that, in turn, is related to the degree of salinity [72,73]. Nevertheless, a unique SSS value can be estimated from the BT only when SST is known. Generally, given the operating frequency and viewing angle of the satellite microware radiometer, larger salinity levels correspond to lower BT values-given SST. As for the derivation of SST products from BT measurements, an accurate SSS retrieval needs the estimation of different factors influencing the radiometer BT (e.g., sea surface roughness) to be removed. As an example, Figure 6 shows a global SSS map on a $40 \mathrm{~km}$-grid obtained from NASA soil moisture active passive (SMAP) measurements collected in the period 4-11 November 2018. SMAP provides L-band $(1.41 \mathrm{GHz})$ BT measurements, with $1.5 \mathrm{~K}$ radiometric sensitivity, over an area of about $1000 \times 100 \mathrm{~km}$, with approximately $40 \mathrm{~km}$ resolution on a weekly basis. In Figure 6, it can be observed that the most promising sites for sampling extremophiles halophiles, i.e., sea areas characterized by extreme salinity values (e.g., larger than $38 \mathrm{psu}$ ) are the Eastern part of the Mediterranean Sea, the Mediterranean coasts of Spain and France, the Italian Seas, the Northern part of the Red Sea, and the Persian Gulf.

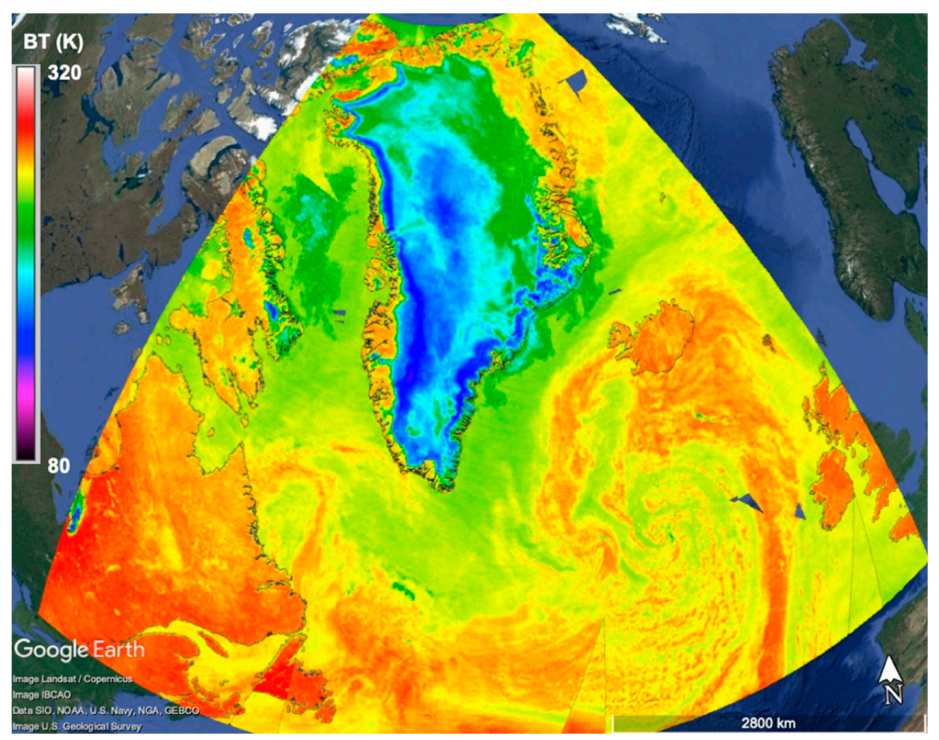

Figure 4. AMSR-E BT measurements, collected at $89.000 \mathrm{GHz}$ over the north Atlantic area on 2 July 2011.

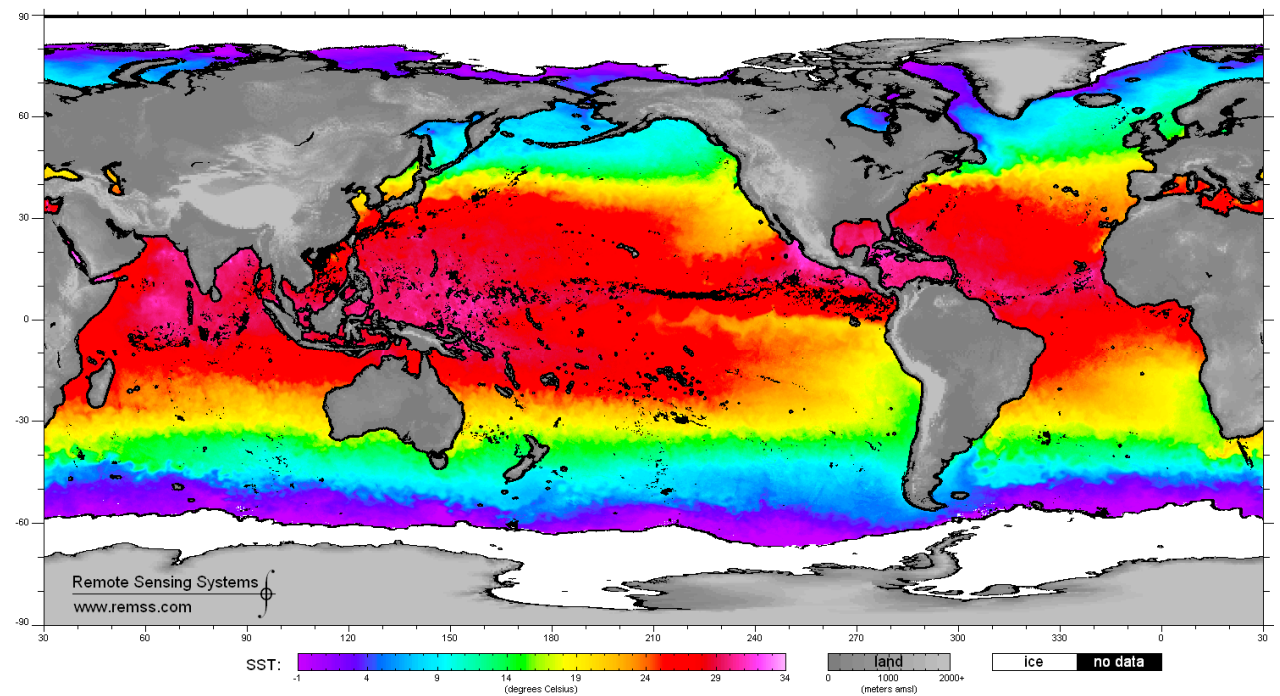

Figure 5. SST global map on $25 \mathrm{~km}$ resolution cell obtained by three-day averaging AMSRE-E measurements collected in the period 2-4 October 2011. 


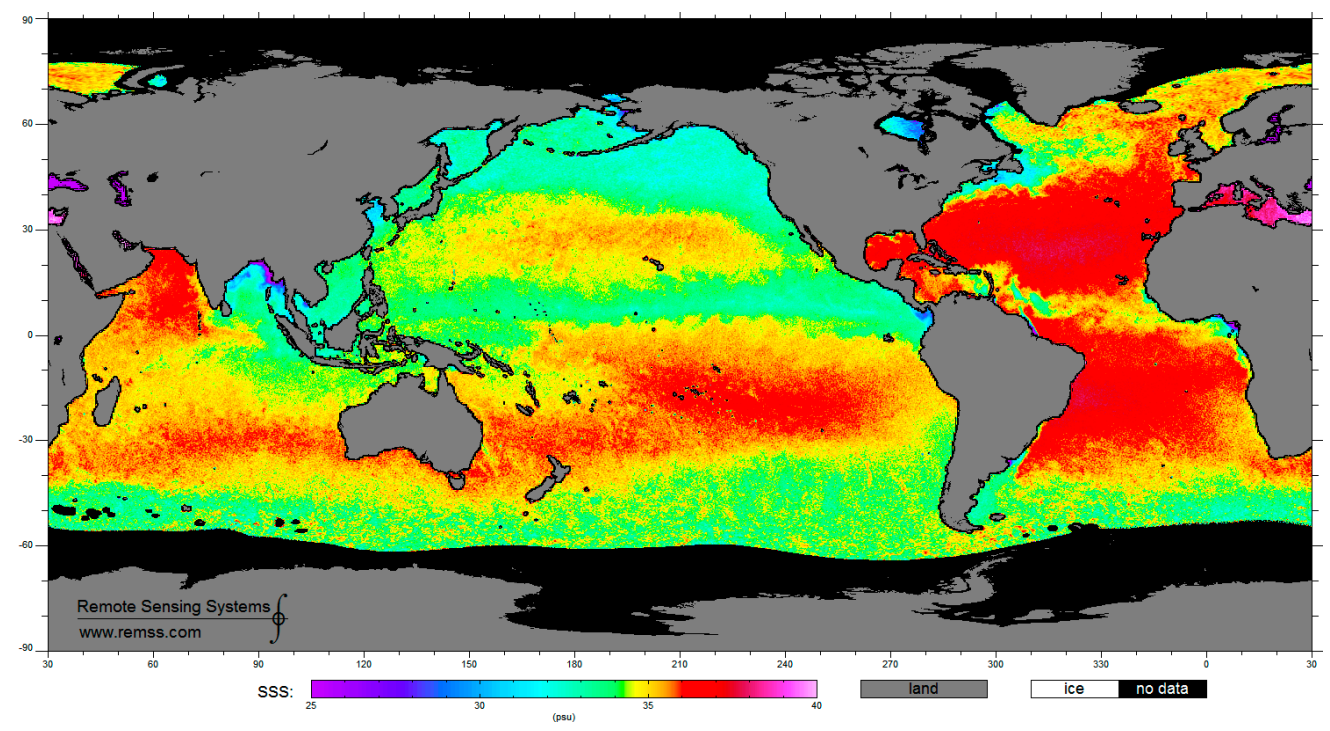

Figure 6. SSS global map on $40 \mathrm{~km}$ resolution cell obtained by eight-day averaging SMAP measurements collected in the period 4-11 November 2018.

The derivation of SIC standard products from microwave radiometers is possible since the microwave emissions from ice over sea surface, due to its crystalline structure, are usually much larger than the surrounding sea $[74,75]$. Even when deriving SIC products, BT measurements need corrections to reduce the influence of several factors as atmospheric water vapor and sea surface roughness. As an example, Figure 7 shows a SIC map on a $10 \mathrm{~km}$-grid obtained from AMSR-2 measurements collected over Antarctica region on 22 November 2018. AMSR-2 provides multi-frequency $(6.930 \mathrm{GHz}$, $7.300 \mathrm{GHz}, 10.650 \mathrm{GHz}, 18.700 \mathrm{GHz}, 23.800 \mathrm{GHz}, 36.500 \mathrm{GHz}$, and $89.000 \mathrm{GHz}$ ) BT measurements, with $0.3-1.1 \mathrm{~K}$ radiometric sensitivity, a swath width of approximately $1450 \mathrm{~km}$, with about $5 \times 3 \mathrm{~km}$ (at $89.000 \mathrm{GHz}$ ) to $62 \times 35 \mathrm{~km}$ (at $6.930 \mathrm{GHz}$ ) spatial resolution on a daily basis. In Figure 7 it can be noted that the highest SIC values are experienced by the Larsen ice shelf and Wilkes land areas, which can be, therefore, potential sites of extremophiles psychrophiles, while very low SIC values characterize the Ross ice shelf, the Pine island bay and the eastern part of the Ronne ice shelf.

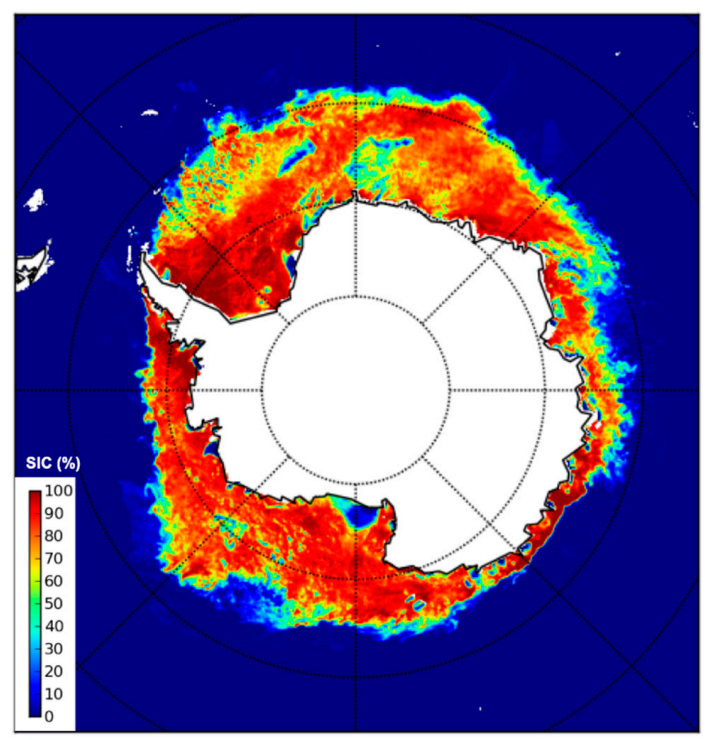

Figure 7. SIC map of Antarctica on $10 \mathrm{~km}$ resolution cell obtained by daily averaging AMSR-2 measurements collected on 22 November 2018 (Copyright (C 2018 EUMETSAT). 


\section{Conclusions}

The extremozymes, i.e., the enzymes produced by microorganisms living in extreme environments, are the focus of great interest for their manifold applications in several fields ranging from the food and pharmaceutical industries, to the conversion of biomass to energy, to the bioremediation of polluted areas. The marine extremozymes are produced by species living in extreme habitats like cold or hypersaline environments, hydrothermal vents or polluted sites. Therefore, marine extremozymes have adapted to harsh conditions and are active in the conditions typical of many industrial processes like extreme temperatures and $\mathrm{pH}$ values, high saline concentrations, and presence of metals and of organic solvents. Indeed, many examples of application of marine extremozymes can be found including the green conversion of different kinds of biomass to biofuels (ethanol, diesel, hydrogen) and the bioremediation of polluted sites in consequence of accidental oil spills or release of contaminants by industrial activities. The enormous biodiversity of marine extremophiles, and therefore the great variety of useful enzymes, is still underexplored. Hence, the identification of new enzyme producing species is a key issue for modern biotechnology that take advantages from exploitation of extremozymes. The identification of new species could be strongly pushed by the combination of different search approaches like metagenomic and remote sensing. Indeed, satellite microwave remote sensing, including active polarimetric SAR sensors and passive radiometers, can effectively support, on a regional/global scale and on a regular basis, a continuous and updated identification of sea sites affected by oil pollution, sea areas characterized by extreme SST and SSS values, and sea ice-infested areas. Such environments are promising sources of extremozymes producers that, thanks to the metagenomic tools, could be easily selected for their potential biotechnology applications.

Author Contributions: For research articles with several authors, a short paragraph specifying their individual contributions must be provided. The following statements should be used "Conceptualization, P.D.D., L.L., A.B.; A.P., A.B.; Investigation, P.D.D., I.F., G.R.A.; Writing-Original Draft Preparation, P.D.D., A.B., L.L., A.P.; Writing-Review \& Editing, P.D.D., A.B., B.N.; Supervision, P.D.D., B.N., A.B.

Funding: This research received no external funding.

Acknowledgments: The authors thank the European Space Agency who provided Sentinel-1 SAR data through the Copernicus scientific hub and the German Space Agency who provided TerraSAR-X SAR data under the AO OCE3201. AMSR-E data and SST/SSS products are produced by Remote Sensing Systems and sponsored by the NASA Earth Science MEaSUREs DISCOVER Project and the AMSR-E Science Team (freely available at Www.remss.com). Sea ice concentration products are produced by the Satellite Application Facility on Ocean and Sea Ice freely available at www.osi-saf.org). The authors also acknowledge the Italian Antarctic Research Program and the project PNRA16_00274.

Conflicts of Interest: The authors declare no conflict of interest.

\section{References}

1. Bolhuis, H.; Cretoiu, M.S. What is so Special about Marine Microorganisms? Introduction to the Marine Microbiome-From Diversity to Biotechnological Potential. In The Marine Microbiome an Untapped Source of Biodiversity and Biotechnological; Stal, L.J., Cretoiu, M.S., Eds.; Springer: Cham, Switzerland, 2016; Chapter 1; pp. 3-20.

2. MacElroy, R.D. Some comments on evolution of extremophiles. Biosystems 1974, 6, 74-75. [CrossRef]

3. Rothschild, L.J.; Mancinelli, R.L. Life in extreme environments. Nature 2001, 409, 1092-1101. [CrossRef] [PubMed]

4. Chandrasekaran, M.; Kumar, S.R. Marine microbial enzymes. In Biotechnology; Werner, H., Roken, S., Eds.; EOLSS: Paris, France, 2010; Volume 9, pp. 47-49.

5. Russo, R.; Giordano, D.; Riccio, A.; di Prisco, G.; Verde, C. Cold-adapted bacteria and the globin case study in the Antarctic bacterium Pseudoalteromonas haloplanktis TAC125. Mar. Genom. 2010, 3, 125-131. [CrossRef]

6. Trincone, A. Potential biocatalysts originating from sea environments. J. Mol. Catal. B-Enzym. 2010, 66, 241-256. [CrossRef] 
7. Fulzele, R.; Desa, E.; Yadav, A.; Shouche, Y.; Bhadekar, R. Characterization of novel extracellular protease produced by marine bacterial isolate from the Indian Ocean. Braz. J. Microbiol. 2011, 42, 1364-1373. [CrossRef] [PubMed]

8. Samuel, P.; Raja, A.; Prabakaran, P. Investigation and application of marine derived microbial enzymes: Status and prospects. Int. J. Oceanogr. Mar. Ecol. Syst. 2012, 1, 1-10. [CrossRef]

9. Poli, A.; Finore, I.; Romano, I.; Gioiello, A.; Lama, L.; Nicolaus, B. Microbial Diversity in Extreme Marine Habitats and Their Biomolecules. Microorganisms 2017, 5, 25. [CrossRef]

10. Mapelli, F.; Crotti, E.; Molinari, F.; Daffonchio, D.; Borin, S. Extreme Marine Environments (Brines, Seeps, and Smokers). In the Marine Microbiome; Stal, L.J., Cretoiu, M.S., Eds.; Springer: Cham, Switzerland, 2016; Chapter 9; pp. 251-282. ISBN 978-3-319-32998-7, 978-3-319-33000-6.

11. Moyer, C.L.; Morita, R.Y. Psychrophiles and Psychrotrophs. In Encyclopedia of Life Sciences; John Wiley \& Sons, Ltd.: Hoboken, NJ, USA, 2007.

12. Caruso, C.; Rizzo, C.; Mangano, S.; Rappazzo, A.C.; Poli, A.; Di Donato, P.; Nicolaus, B.; Di Marco, G.; Michaud, L.; Lo Giudice, A. Extracellular polymeric substances with metal adsorption capacity produced by Pseudoalteromonas sp. MER144 from Antarctic seawater. Environ. Sci. Pollut. Res. Int. 2018, 25, 4667-4677. [CrossRef]

13. Breezee, J.; Cady, N.; Staley, J.T. Subfreezing growth of the sea ice bacterium 'Psychromonas ingrahamii'. Microb. Ecol. 2004, 47, 300-304. [CrossRef]

14. Franzmann, P.D.; Liu, Y.; Balkwill, D.L.; Aldrich, H.C.; De Macario, E.C.; Boone, D.R. Methanogenium frigidum sp. nov.; a psychrophilic, H2-using methanogen from Ace Lake, Antarctica. Int. J. Syst. Bacteriol. 1997, 47, 1068-1072. [CrossRef]

15. Caruso, C.; Rizzo, C.; Mangano, S.; Poli, A.; Di Donato, P.; Finore, I.; Nicolaus, B.; Di Marco, G.; Michaud, L.; Lo Giudice, A. Production and biotechnological potentialities of extracellular polymeric substances from sponge-associated Antarctic bacteria. Appl. Environ. Microbiol. 2018, 84, e01624-17.

16. Caruso, C.; Rizzo, C.; Mangano, S.; Poli, A.; Di Donato, P.; Nicolaus, B.; Finore, I.; Di Marco, G.; Michaud, L.; Lo Giudice, A. First evidence of extracellular polymeric substance production by a cold-adapted Marinobacter isolate from Antarctic seawater. Antarct. Sci. 2018, in press.

17. Methé, B.A.; Nelson, K.E.; Deming, J.W.; Momen, B.; Melamud, E.; Zhang, X.J.; Moult, J.; Madupu, R.; Nelson, W.C.; Dodson, R.J.; et al. The psychrophilic lifestyle as revealed by the genome sequence of Colwellia psychrerythraea $34 \mathrm{H}$ through genomic and proteomic analyses. Proc. Natl. Acad. Sci. USA 2005, 102, 10913-10918. [CrossRef]

18. Médigue, C.; Krin, E.; Pascal, G.; Barbe, V.; Bernsel, A.; Bertin, P.N.; Cheung, F.; Cruveiller, S.; D'Amico, S.; Duilio, A.; et al. Coping with cold: The genome of the versatile marine Antarctica bacterium Pseudoalteromonas haloplanktis TAC125. Genome Res. 2005, 15, 1325-1335. [CrossRef]

19. Bowman, J.P. Genomics of Psychrophilic Bacteria and Archaea. In Psychrophiles: From Biodiversity to Biotechnology; Margesin, R., Ed.; Springer: Cham, Switzerland, 2017.

20. Martin, W.; Baross, J.; Kelley, D.; Russell, M.J. Hydrothermal vents and the origin of life. Nat. Rev. Microb. 2008, 6, 805-814. [CrossRef]

21. Tarasov, V.G.; Propp, M.V.; Propp, L.N. Functions of the coastal marine ecosystems in relation of hydrothermal venting. Ecol. Chim. 2002, 11, 1-15.

22. Maugeri, T.L.; Bianconi, G.; Canganella, F.; Danovaro, R.; Gugliandolo, C.; Italiano, F.; Lentini, V.; Manini, E.; Nicolaus, B. Shallow hydrothermal vents in the southern Tyrrhenian Sea. Chem. Ecol. 2010, 26, 285-298. [CrossRef]

23. Hekinian, R.; Renard, V.; Cheminee, J.L. Hydrothermal deposits on the East Pacific Rise near $13^{\circ}$ N: Geological setting and distribution of active sulfide chimneys. In Hydrothermal Processes at Seafloor Spreading Centers; Rona, P.A., Bostrom, K., Laubier, L., Smith, K.L., Jr., Eds.; Plenum Press: New York, NY, USA, 1984; pp. 571-594.

24. Tarasov, V.G.; Gebruk, A.V.; Mironov, A.N.; Moskalev, L.I. Deep-sea and shallow-water hydrothermal vent communities: Two different phenomena? Chem. Geol. 2005, 224, 5-39. [CrossRef]

25. Karl, D.M. The Microbiology of Deep-Sea Hydrothermal Vents; Karl, D.M., Ed.; CRC Press: Boca Raton, FL, USA, 1995.

26. Takai, K.; Komatsu, T.; Inagaki, F.; Horikoshi, K. Distribution of Archaea in a black smoker chimney structure. Appl. Environ. Microbiol. 2001, 67, 618-629. [CrossRef] 
27. Oren, A. Industrial and environmental applications of halophilic microorganisms. Environ. Tech. 2010, 31, 825-834. [CrossRef]

28. Oren, A. Life at high salt conditions. In the Prokaryotes. A Handbook on the Biology of Bacteria: Ecophysiology and Biochemistry; Dworkin, M., Falkow, S., Rosenberg, E., Schleifer, K.H., Stackebrandt, E., Eds.; Springer: New York, NY, USA, 2006; Volume 2, pp. 263-282.

29. DasSarma, S.; DasSarma, P. Halophiles. In Encyclopedia of Life Sciences; John Wiley \& Sons, Ltd.: Chichester, UK, 2012.

30. Poli, A.; Kazak, H.; Gürleyendag, B.; Tommonaro, G.; Pieretti, G.; Toksoy Öner, E.; Nicolaus, B. High level synthesis of levan by a novel Halomonas species growing on defined media. Carbohydr. Polym. 2009, 78, 651-657. [CrossRef]

31. Hasan, U.Ö.; Berna, S.A.; Burak, A.; Poli, A.; Denizci, A.A.; Utkan, G.; Nicolaus, B.; Kazan, D. Moderately Halophilic Bacterium Halomonas sp. AAD12: A promising candidate as a Hydroxyectoine Producer. J. Microbial. Biochem. Technol. 2015, 7, 262-268.

32. Romano, I.; Poli, A.; Finore, I.; Huertas, F.J.; Gambacorta, A.; Pelliccione, S.; Nicolaus, G.; Lama, L.; Nicolaus, B. Haloterrigena hispanica sp. nov.; an extremely halophilic archaeon from Fuente de Piedra, Southern Spain. Int. J. Syst. Evol. Microbiol. 2007, 57, 1499-1503. [CrossRef] [PubMed]

33. Romano, I.; Finore, I.; Nicolaus, G.; Huertas, F.J.; Lama, L.; Nicolaus, B.; Poli, A. Halobacillus alkaliphilus sp. nov.; a halophilic bacterium isolated from a salt lake in Fuente de Piedra, Southern Spain. Int. J. Syst. Evol. Microbiol. 2008, 58, 886-890. [CrossRef] [PubMed]

34. Romano, I.; Orlando, P.; Gambacorta, A.; Nicolaus, B.; Dipasquale, L.; Pascual, J.; Giordano, A.; Lama, L. Salinivibrio sharmensis sp. nov, a novel haloalkaliphilic bacterium from a saline lake in Ras Mohammed Park (Egypt). Extremophiles 2011, 15, 213-220. [CrossRef] [PubMed]

35. Moreno, M.L.; Pérez, D.; García, M.T.; Mellado, E. Halophilic bacteria as a source of novel hydrolytic enzymes. Life 2013, 3, 38-51. [CrossRef] [PubMed]

36. Dalmaso, G.Z.L.; Ferreira, D.; Vermelho, A.B. Marine extremophiles: A source of hydrolases for biotechnological applications. Mar. Drugs 2015, 13, 1925-1965. [CrossRef]

37. Trincone, A. Enzymatic Processes in Marine Biotechnology. Mar. Drugs 2017, 15, 93. [CrossRef]

38. Annamalai, N.; Rajeswari, M.; Balasubramanian, T. Enzymatic saccharification of pretreated rice straw by cellulase produced from Bacillus carboniphilus CAS 3 utilizing lignocellulosic wastes through statistical optimization. Biomass Bioenergy 2014, 68, 151-160. [CrossRef]

39. Kim, B.; Lee, B.; Lee, Y.; Jin, I.; Chung, C.; Lee, J. Purification and characterization of carboxymethylcellulase isolated from a marine bacterium, Bacillus subtilis subsp. subtilis A-53. Enzym. Microb. Technol. 2009, 44, 411-416. [CrossRef]

40. Annamalai, N.; Rajeswari, M.V.; Elayaraja, S.; Thavasi, R.; Vijayalakshmi, S.; Balasubramanian, T. Purification and Characterization of Thermostable Alkaline Cellulase from Marine Bacterium Bacillus licheniformis AU01 by Utilizing Cellulosic Wastes Waste Biomass. Valorization 2012, 3, 305-310. [CrossRef]

41. Purwani, N.N.; Darmokoesoemo, H.; Tri Puspaningsih, N.N. Hydrolysis of Corncob Xylan using -xylosidase GbtXyl43B from Geobacillus thermoleovorans IT-08 Containing Carbohydrate Binding Module (CBM). Procedia Chem. 2016, 18, 75-81. [CrossRef]

42. Harshvardhan, K.; Mishra, A.; Jha, B. Purification and characterization of cellulase from a marine Bacillus sp. H1666: A potential agent for single step saccharification of seaweed biomass. J. Mol. Catal. B Enzym. 2013, 93, 51-56. [CrossRef]

43. Yagi, H.; Fujise, A.; Itabashi, N.; Ohshiro, T. Purification and characterization of a novel alginate lyase from the marine bacterium Cobetia sp. NAP1 isolated from brown algae. Biosci. Biotechnol. Biochem. 2016, 80, 2338-2346. [CrossRef]

44. Mohapatra, B.R. Kinetic and thermodynamic properties of alginate lyase and cellulase co-produced by Exiguobacterium species Alg-S5. Int. J. Biol. Macromol. 2017, 98, 103-110. [CrossRef]

45. Alkotaini, B.; Han, N.S.; Kim, B.S. Enhanced catalytic efficiency of endo- $\beta$-agarase I by fusion of carbohydrate-binding modules for agar prehydrolysis. Enzym. Microb. Technol. 2016, 93-94, 142-149. [CrossRef]

46. Charoenpanich, J.; Suktanaraga, S.; Toobbucha, N. Production of a thermostable lipase by Aeromonas sp. EBB-1 isolated from marine sludge in Angsi1la. Thail. Sci. Asia 2011, 37, 105-114. [CrossRef] 
47. Mehrasbi, M.; Mohammadi, J.; Peyda, M.; Mohammadi, M. Covalent immobilization of Candida antarctica lipase on core-shell magnetic nanoparticles for production of biodiesel from waste cooking oil. Renew. Energy 2017, 101, 593-602. [CrossRef]

48. Yang, K.; Sohn, J.; Kim, H. Catalytic properties of a lipase from Photobacterium lipolyticum for biodiesel production containing a high methanol concentration. J. Biosci. Bioeng. 2009, 107, 599-604. [CrossRef]

49. Wu, Y.; Mao, A.; Sun, C.; Shanmugam, S.; Li, J.; Zhong, M. Catalytic hydrolysis of starch for biohydrogen production by using a newly identified amylase from a marine bacterium Catenovulum sp. X3. Int. J. Biol. Macromol. 2017, 104 Pt A, 716-723. [CrossRef]

50. Sivaperumal, P.; Kamala, K.; Rajaram, R. Bioremediation of Industrial Waste through Enzyme Producing Marine Microorganisms. Adv. Food Nutr. Res. 2017, 80, 165-179. [PubMed]

51. da Fonseca, F.; Angolini, C.; Zezzi Arruda, M.; Junior, C.; Santos, C.; Saraiva, A.; Pilau, E.; Souza, A.; Laborda, P.; de Oliveira, P.; et al. Identification of oxidoreductases from the petroleum Bacillus safensis strain. Biotechnol. Rep. 2015, 8, 152-159. [CrossRef] [PubMed]

52. Fang, Z.; Li, T.; Chang, F.; Zhou, P.; Fang, W.; Hong, Y.; Zhang, X.; Peng, H.; Xiao, Y. A new marine bacterial laccase with chloride-enhancing, alkaline-dependent activity and dye decolorization ability. Bioresour. Technol. 2012, 111, 36-41. [CrossRef] [PubMed]

53. Wang, L.; Wang, W.; Lai, Q.; Shao, Z. Gene diversity of CYP153A and AlkB alkane hydroxylases in oil-degrading bacteria isolated from the Atlantic Ocean. Environ. Microbiol. 2010, 12, 1230-1242. [CrossRef] [PubMed]

54. Saito, A.; Iwabuchi, T.; Harayama, S. A novel phenanthrene dioxygenase from Nocardioides sp. Strain KP7: expression in Escherichia coli. J. Bacteriol. 2000, 182, 2134-2141. [CrossRef] [PubMed]

55. Nikolaivits, E.; Dimarogona, M.; Fokialakis, N.; Topakas, E. Marine-Derived Biocatalysts: Importance, Accessing, and Application in Aromatic Pollutant Bioremediation. Front. Microbiol. 2017, 8, 265. [CrossRef] [PubMed]

56. Zhang, J.; Cao, X.; Xin, Y.; Xue, S.; Zhang, W. Purification and characterization of a dehalogenase from Pseudomonas stutzeri DEH130 isolated from the marine sponge Hymeniacidon perlevis. World J. Microbiol. Biotechnol. 2013, 29, 1791-1799. [CrossRef]

57. Zhang, J.; Xin, Y.; Cao, X.; Xue, S.; Zhang, W. Purification and characterization of 2-haloacid dehalogenase from marine bacterium Paracoccus sp. DEH99, isolated from marine sponge Hymeniacidon perlevis. J. Ocean Univ. China 2014, 13, 91-96. [CrossRef]

58. Novak, H.R.; Sayer, C.; Panning, J.; Littlechild, J.A. Characterisation of an 1-haloacid dehalogenase from the marine psychrophile Psychromonas ingrahamii with potential industrial application. Mar. Biotechnol. 2013, 15, 695-705. [CrossRef]

59. Li, A.; Shao, Z. Biochemical characterization of a haloalkane dehalogenase DadB from Alcanivorax dieselolei B-5. PLoS ONE 2014, 9, e89144. [CrossRef]

60. Ulaby, F.T.; Moore, R.K.; Fung, A.K. Microwave Remote Sensing: Active and Passive; Artech House: Norwood, MA, USA, 1981.

61. Fung, K.; Chen, K.S. Microwave Scattering and Emission Models for Users; Artech House: Norwood, MA, USA, 1996.

62. Kanevsky, M.B. Radar Imaging of Ocean Waves; Elsevier: Jordan Hill, UK, 2009.

63. Donlon, C.; Berruti, B.; Buongiorno, A.; Ferreira, M.-H.; Femenias, P.; Frerick, J.; Goryl, P.; Klein, U.; Laur, H.; Mavrocordatos, C.; et al. The global monitoring for environment and security (GMES) Sentinel-3 mission. Remote Sens. Environ. 2012, 120,37-57. [CrossRef]

64. Bonekamp, H.; Montagner, F.; Santacesaria, V.; Noddo, C.N.; Wannop, S.; Tomazic, I.; O'Carroll, A.; Kwiatkowska, E.; Scharroo, R.; Wilson, H. Core operational Sentinel-3 marine data product services as part of the Copernicus space component. Ocean Sci. 2016, 12, 787-795. [CrossRef]

65. Lee, J.-S.; Pottier, C. Polarimetric Radar Imaging: From Basics to Applications; CRC Press: Boca Raton, FL, USA, 2009.

66. Van Zyl, J.; Kim, Y. Synthetic Aperture Radar Polarimetry; JPL Space Science and Technology Series; NASA: Washington, DC, USA, 2010.

67. Wentz, F.J.; Gentemann, C.L.; Smith, D.K.; Chelton, D. Satellite measurements of sea surface temperature through clouds. Science 2000, 288, 847-850. [CrossRef] 
68. Hosoda, K. Review of satellite-based microwave observations of sea surface temperatures. J. Oceanogr. 2010, 66, 439-473. [CrossRef]

69. Migliaccio, M.; Nunziata, F.; Buono, A. SAR polari0metry for sea oil slick observation. Int. J. Remote Sens. 2015, 36, 3243-3273. [CrossRef]

70. Nunziata, F.; Buono, A.; Migliaccio, M. COSMO-SkyMed Synthetic Aperture Radar data to observe the Deepwater Horizon oil spill. Sustainability 2018, 10, 3959. [CrossRef]

71. Nunziata, F.; de Macedo, C.R.; Buono, A.; Velotto, D.; Migliaccio, M. On the analysis of a time series of X-band TerraSAR-X SAR imagery over oil seepages. Int. J. Remote Sens. 2018, in press. [CrossRef]

72. Meissner, T.; Wentz, F.J.; Le Vine, D.M. The salinity retrieval algorithms for the NASA Aquarius version 5 and SMAP version 3 releases. Remote Sens. 2018, 10, 1121. [CrossRef]

73. Lagerloef, G.S.E. Satellite Remote Sensing: Salinity Measurements, Encyclopedia of Ocean Sciences; Academic Press: Cambridge, MA, USA, 2009.

74. Tikhonov, V.V.; Raev, M.D.; Sharkov, E.A.; Boyarskii, D.A.; Repina, I.A.; Komarova, N. Satellite microwave radiometry of sea ice of polar regions: A review. Atmos. Ocean. Phys. 2016, 52, 1012-1030. [CrossRef]

75. Ivanova, N.; Pedersen, L.T.; Tonboe, R.T.; Kern, S.; Heygster, G.; Lavergne, T.; Sørensen, A.; Saldo, R.; Dybkjær, G.; Brucker, L.; et al. Inter-comparison and evaluation of sea ice algorithms: Towards further identification of challenges and optimal approach using passive microwave observations. Cryosphere 2015, 9, 1797-1817. [CrossRef]

(C) 2018 by the authors. Licensee MDPI, Basel, Switzerland. This article is an open access article distributed under the terms and conditions of the Creative Commons Attribution (CC BY) license (http:/ / creativecommons.org/licenses/by/4.0/). 